\title{
Penicillin Antibiotic
}

National Cancer Institute

\section{Source}

National Cancer Institute. Penicillin Antibiotic. NCI Thesaurus. Code C1500.

Any beta-lactam antibiotic derived from Pencillium fungi with bactericidal activity. Penicillin antibiotics bind to and inactivate penicillin-binding proteins (PBPs) located on the inner membrane of the bacterial cell wall. Inactivation of PBPs interferes with the cross-linkage of peptidoglycan chains necessary for bacterial cell wall strength and rigidity. This interrupts bacterial cell wall synthesis and results in the weakening of the bacterial cell wall, eventually causing cell lysis. 